doi: $10.19090 /$ i.2021.32.162-174

UDC: 929 Jeftanović G.

ISTRAŽIVANJA

JOURNAL OF HISTORICAL RESEARCHES

32 (2021)
ORIGINAL SCIENTIFIC PAPER

Received: 30 November 2020

Accepted: 10 March 2021

\author{
BOŠKO M. BRANKOVIĆ \\ University of Banja Luka \\ Faculty of Philosophy \\ bosko.brankovic@ff.unibl.org
}

\title{
GLIGORIJE JEFTANOVIĆ AND THE STRUGGLE FOR CHURCH AND SCHOOL AUTONOMY
}

\begin{abstract}
The first part of this paper presents a brief history of the beginning and course of the Serbian people's struggle in the provinces of Bosnia-Herzegovina for Church and school autonomy and the role Gligorij Jeftanović played as one of the two most important figures leading the movement. The second part of the paper deals with correspondence between Gligorije Jeftanović and Lazar Pupić in 1901 during the time a Serbian envoy was being selected to travel from Sarajevo to Constantinople and attempt to win over the Ecumenical Patriarch to the Serbian cause by gaining support for the Third Imperial Memorandum. It also looks at correspondence after the election with the chosen envoy, Kosta Kujundžić, who tried but failed to win the Ecumenical Patriarch over to the Serbian side. The third part deals the adoption of the Statute on Church and School Autonomy and the decline in Gligorije Jeftanović's popularity after the emergence of a young, university-educated Serbian intelligentsia, which had new ideas and demands concerning new goals for the continuation of the struggle.

Keywords: Gligorije Jeftanović, Church and school autonomy, struggle, Austro-Hungarian Monarchy, Ecumenical Patriarchate, Serbs, Bosnia-Herzegovina.
\end{abstract}

$\mathrm{T}$

The struggle of the Serbian people for greater freedoms and rights in Herzegovina and Bosnia gained momentum at the beginning of the nineteenth century, which manifested itself particularly through revolts and uprisings, beginning with Jančić's Rebellion and continued with Priest Jovica's Rebellion, Luka Vukalović's Uprising, and the Herzegovina Uprising of 1875. After this period, the Serbs continued advocating for autonomy for, or the complete liberation of, these provinces under Ottomom rule. Also, Serbs increasingly pled their case before the Ottoman authorities regarding their national rights. The issue of the rights of Serbs in the provinces of Bosnia-Herzegovina became particularly timely in the middle of the nineteeth century when Serbs began to strive for liberation and for unity with Serbia and other Serbian countries. As the Serbian people's desire for liberation grew, so did the European countries' diplomatic activities regarding the fate of these provinces. ${ }^{1}$ Serbia, the Austro-Hungarian Monarchy, and the Ottoman Empire

1 Branković 2015: 37; Marković 2020: 423-424. 
had the most influence on diplomatic negotiations. In addition, Russia and Great Britain also played an important role, as did France, Itally, and Germany. The concept of handing over the administration of these provinces over to the people, who would be overseen by the Austro-Hungarian Monarchy on behalf of the European states, emerged after Luka Vukalović's Uprising in Herzegovina $1852-1862 .{ }^{2}$ However, this never transpired because the uprising collapsed. ${ }^{3}$

The Uprising of 1875, when Serbs in Bosnia-Herzegovina revolted against the Ottoman state, resulted in the Serbs in these provinces asking the Great European Powers for the first time for the opportunity to join with Serbia and Montenegro. This year was a turning point in cooperation within the triangle of Serbia, Montenegro, and the Serbs in BosniaHerzegovina. However, not all of the European states looked favorably on the possibility of these provinces gaining autonomy or joining Serbia and Montenegro. ${ }^{4}$ The biggest opponent to these ideas was the president of the joint government of the Austro-Hungarian Monarchy, Gyula Andrássy. Andrássy not only opposed the idea of annexing the provinces to Serbia and Montenegro; he also rejected the possibility of them gaining autonomy. Andrássy rationalized his rejection of all the insurgents' demands by asserting that, in the future, this could potentially lead to the unification of these provinces with Serbia and Montenegro. In addition to the Austro-Hungarian Monarchy, the government of Great Britain also opposed autonomy. ${ }^{5}$ Benjamin Disraeli, when comparing the question of autonomy for BosniaHerzegovina with that of Ireland, wrote in a letter on October 1, 1875, 'Fancy autonomy for Bosnia with a mixed population; autonomy for Ireland would be less absurd' ${ }^{6}$

All this did not go in favor of the Serbian people and their struggle for liberation, which in the end proved to be correct: The Austro-Hungarian Monarchy took possession of the Ottoman provinces of Bosnia-Herzegovina on the basis of Article XXV of the 1878 Treaty of Berlin and the Austro-Turkish Convention of April 29, 1879. The Imperial Command knew the greatest threat to the new Austro-Hungarian rule was the possibility of joint action by Serbs and Muslims, so it sent instructions to General Josip Filipović, commander of the Austro-Hungarian troops, which included a binding directive for the troops to deal with the local population according to the principle of DIVIDE ET IMPERA. General Filipović was advised to work on establishing an alliance of Muslims and Catholics and to prevent any sort of rapprochement between Muslims and Serbs. ${ }^{7}$

One of the most important issues for the Austro-Hungarian government in the provinces of Bosnia-Herzegovina was regulating the status of religious communities. Vienna was particularly concerned with the organization of the Serbian Orthodox Church because it sought to influence Serbian parish clergy and the Serbian people through the Church hierarchy. Vienna conducted negotiations with the Ecumenical Patriarchate regarding the status of the Serbian Orthodox Church in the provinces of BosniaHerzegovina, which resulted in the conclusion of the Convention of March 28, 1880, which

Slijepčević 1981: 27; Branković 2015: 38.

Mikić 2012: 523; Berić 1994: 33.

Branković 2015: 42.

Mikić 2012: 525; Ković 2007: 149-150; Branković 2015: 41.

Ković 2007: 142; Mikić 2012: 526; Branković 2015: 42.

Juzbašić 1978: 145-146; Branković 2017a: 89. 
granted the Austro-Hungarian ruler the right to appoint and replace archbishops without the people's participation and would only need to inform the Ecumenical Patriarch of the leaders' decisions. ${ }^{89}$ In addition to regulating religious life, the Austro-Hungarian government also tried to regulate Serbian religious schools by gradually banning the inclusion of the national name in school names and the use of the Cyrillic script. ${ }^{111}$

The Serbian Movement for Church and School Autonomy, which officially began in 1896, exposed public dissatisfation with the repression of the populace, which primarily deprived them of the rights acquired under the Ottoman Empire after centuries of struggle for survival and the preservation of their identity and religion, and which had been guaranteed by the Austro-Hungarian ruler when the Austro-Hungarian government was established. ${ }^{12}$

The Serbian movement for self-management of confessional schools pushed the city elite onto the historical stage. The Provincial Government explained the leading role the city elite took in the Serbian movement with the fact that Serbian citizens had also lost political influence among the Serbian population though economic setbacks. However, it is evident that the authorites had overemphasized the Serbs' economic decline, while also ignoring the fact that it had been caused by the government, which had limited economic progress by favoring foreign capital. ${ }^{13}$

The joint emergence of many Serbian communes in 1896 meant the creation of an origanized movement led by Gligorije Jeftanović of Sarajevo, Vojislav Šola and Vladimir Radović of Mostar, Kosta Kujundžić of Livno, Pero Drljača of Bosanski Novi, Bogdan Milanović of Bosnanski Petrovac, and others. The most prominent of these were Gligorije Jeftanović ${ }^{14}$ and Vojislav Šola. ${ }^{15}$ Over time, a cult of personality was built around the leaders of the Serbian movement that reached 'unusual heights, and many other great historical figures did not enjoy such respect during their short lives as merciful destiny had bestowed upon these [leaders]'. ${ }^{16}$ A comment from one source aserves as the best testimony as to how Gligorije Jeftanović was regarded during the struggle for educational autonomy: '[He was] respected as a demigod, bathed in flowers, his picture with a hymn dedicated to him stood

\footnotetext{
Madžar, Papić 2005: 9; Branković 2017a: 89.

Šneler 1893: 37-41; Branković 2017a: 90; Vasin 2017: 58; Tomić 2019: 332; Lotoc'kî̂ 1938: 175.

Milošević, Lukić 2020: 145.

Kraljačić 1987: 178; Papić 1982: 115; Branković, Milošević 2016: 14.

Giljferding 1972: 120; Hadžijahić 1970: 56; Branković, Milošević 2016: 14-15; Branković 2018: 181-182.

Kraljačić 1987: 373; Branković 2017b: 28.

4 Gligorije Jeftanović (b. Sarajevo, February 7 1840, d. Sarajevo, March 15, 1927) was a businessman, landowner, national leader, and politician. He served as vice-president of the High Council for Administration and Education. In 1910, he entered the Bosnian Assembly as an active member, and served on the financial, budget, and regulatory commitees. After the People's Assembly was established in Bosnia-Herzegovina in October 1918, he was elected president of the Central Committee. Later, on behalf of the National Council of Bosnia-Herzegovina, he was delegated to the plenum of the National Council of Serbs, Croats, and Slovenes in Zagreb, and after World War I he was selected for the Interim People's Presidency of the Kingdom of Serbs, Croats, and Slovenes. As the the oldest representative in 1919, he served as the first interim president of the assembly. Branković 2019: 189; Urić 2009: 399-401; Kobasica 1927; Madžar 1982: 133, 171; Kruševac 1960: 290, 391; Tomić 2019: 341; Radojčić 2009: 130.

15 Branković 2017b: 28, 29.

16 Vlatković 1979: 333.
} 
with all Orthodox Serbs alongside icons' ${ }^{17}$

From the very start, Gligorije Jeftanović found himself among people fighting for confessional school freedoms and the rights of the Serbian people in Bosnia-Herzegovina. Thus in 1893, he was part of a deputation representing twenty-five Bosnian communes in Bosnia, which met in Sarajevo on April 28, 1893 to draw up a memorandum to submit to the Provincial Government regarding the violation of Serbian Orthodox schools' autonomy in choosing and appointing their own teachers. ${ }^{18}$ Jeftanović became of interest for the authorities as one of the oppositionists when he was heading the deputation of the Sarajevo commune, which traveled to Vienna on November 22, 1896 at the same time as a deputation of Mostar communes headed by Vojislav Šola and a deputation of twelve more communes that had come to appeal to the government and the emperor concerning the injustices the Serbian people were being subjected to regarding the right to Church and school autonomy. ${ }^{19}$ The deputations were able to submit a joint memorandum ${ }^{20}$ to the emperor through Benjamin Kállay on December 27, 1896.

Gligorije Jeftanović was also part of the deputation of Serb communes that traveled to Vienna in February 1897 to draft and submit another imperial memorandum. At that time, Jeftanović and Šola traveled to Prague to seek support for the Serbian question in BosniaHerzegovina from Czech political groups. The deputation managed to submit a memorandum on March 31. ${ }^{21}$ After receiving a negative reply from the Austrian emperor, the leaders of the Serbian movement for autonomy did not give up and were not discouraged by the decision. Jeftanović immediately began a tour of some of the communes to stir up agitatation.

The next meeting of the commune representatives was held in Sarajevo on March 22,1898 , at which it was decided that Jeftanović, Šola, and Vladimir Radović would be sent to Vienna to again lodge a complaint with the emperor regarding the plight of the Serbian people. Since the audience with the emperor had come to nothing, the three-member deputation of the Serbian autonomous movement were given an audience with Benjamin Kállay. The government considered the meeting to be a private visit with the troika. Kállay proposed that Jeftanović, Radović, and Šla draft a statute regarding the organization of the Serbian Orthodox Church in the provinces of Bosnia-Herzegovina, which would be adapted to the political situation in the provinces and the government's relationship to the Ecumenical Patriarch. What displeased the Serbian deputation were requests that the statute be drafted as quietly as possible and without convening a public assembly. The deputation

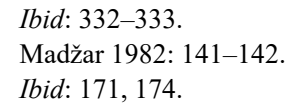

The first imperial memorandum can be divided in three sections: The first asserted that the Serbs in BosniaHerzegovina enjoyed the right to self-management in Church and school matters, and that the Monarchy was required to uphold and respect this acquired right. The second presented evidence that the Austro-Hungarian authorities had limited and stifled Church and school autonomy and all forms of Serbian national expression. The third part presented requests and suggestions to resolve several issues regarding the Church and schools. After the first one, they sent three more memoranda with similar accusations against the Austro-Hungarian authorities. The fourth memorandum of 1902 presented new information, such as a request for a resolution of agrarian issues. Among other things, it mentioned the precarious state of agricultural and skilled trades and the markets, as well as deforestation, foreign colonization, and their complete domination of the public administration.

21 Madžar 1982: 201, 203, 204. 
rejected these proposals at first, but later reconsidered and accepted them. ${ }^{22}$ Šola and Jeftanović returned to Sarajevo on April 5, and at a meeting the following day with Kosta Kujundžić, Mitar Popadić, Lazar Jovanović, Pero Drljača, and Emil Gavrila, they agreed to begin drafting the statute.

After Emil Gavrila and his associates finished what was called the Statute of Church and School Self-Management in Bosnia-Herzegovina, the deputation led by Gligorije Jeftanović took it to Minister Kállay on July 7, $1898 .{ }^{23}$ After realizing that Kállay's promise had in fact been empty, the leaders of the movement for Serbian autonomy decided to turn to the Ecumenical Patriarch, and they left for Constantinople on July 10. In August, however, after reviewing the statute, the patriarch demonstrated his commitment to Vienna. A Synod regarding the decision about the fate of the statute was convened in September 1898 after a commission evalutating the statute had completed its review. Following the commission's recommendation, the Synod rejected the statute. ${ }^{24}$ Emil Gavrila held Dimitrije Ruvarac responsible for the rejection of what was referred to as 'the Jeftanovic statute' by alluding to the fact that the statute was so liberal that not a single Christian people in Europe had something like it. ${ }^{25}$

After a three-month struggle, the leaders of the movement for Serbian autonomy decided to return to Bosnia-Herzegovina to further discuss raising the issue of the statute again with the Ecumenical Patriarchate. At the beginning of April 1899. before their return, they sent a letter to the celebrated leadership of the Young Czechs Club in Vienna thanking them for the moral support offered to them by the Czech people. ${ }^{26}$ After lengthy negotiations and communication with various people in and outside Bosnia-Herzegovina, the Serbian opposition concluded that it would need to change tactics because the Ecumenical Patriarch was clearly more favorably disposed toward Vienna. ${ }^{27}$ Negotiations began with the metropolitans in Bosnia-Herzegovina, which Vienna followed closely. However, in 1899 no agreement was reached. In May 1900, negotiations between the leaders of the Serbian movement and the metropolitans came to a definitive end, and the leaders turned to drafting a new memorandum to be sent to the Austro-Hungarian emperor. An extensive memorandum was compiled in May 1900 explaining in detail what had resulted from the negotiations with the metropolitans, and in May 1900, a deputation left for Budapest to present the memorandum to the emperor. The deputation was headed by Jeftanović. After arriving in Budapest, the deputation was not permitted an audience with the emperor until Kállay had looked over contents of the memorandum. After receiving the memorandum, Kállay suggested that Jeftanović and Šola remain while the rest of the deputation returned to Bosnia-Herzegovina, because the two of them would be more likely to be granted an audience with the emperor. Jeftanović undoubtedly was suspicious of Kállay's sincerity. ${ }^{28}$

After waiting for a year, the members of the Serbian opposition were finally granted

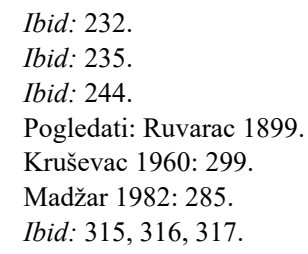


an audience with the emperor on May 30, 1901. It was then that Jeftanović and Šola presented a third memorandum to the emperor. According to official records, the emperor told them, 'I will order contents of the testimonial handed over today be given proper scrutiny, and that the metropolitans of Bosnia-Herzegovina will also be consulted, also as they have the right to be invited first to present their views regarding all religious and ecclesiastical issues. After that, you will be notified of My decision through My Provincial Government in Sarajevo' ${ }^{29}$

In April and May of 1901, there was a great deal of activity related to confessional school autonomy and the Serbian deputation's upcoming audience with the emperor. The Austro-Hungarian authorities tried everything they could to control the way upcoming events unfolded. At the same time, the leaders of the movement prepared to travel again to Constantinople to speak with the Patriarch and try once again to gain his support, despite the previous failures and the Patriarch's sympathy toward Vienna. ${ }^{30}$ The government tried everything it could to control this and to weaken the Serbian movement. They tried to accomplish this through bishops in Bosnia-Herzegovina who were loyal to them, and Jeftanović learned of it in a timely manner through his associates in the provinces.

Gligorije Jeftanović received reliable information about the Metropolitan of Banja Luka-Bihać, Evgeni Letica, through Todor Pišteljić, a connection of his in Banja Luka. On April 25, 1901, he informed Jeftanović that the metropolitan had said the day before that he had received a letter from Metropolitan Nikolaj Mandić of Sarajevo, which stated that, 'the people's leaders were not satisfied with the metropolitan's answer', and that, in agreement with Emil Gavrila, the people's leaders had compiled a new dispatch for the metropolitans, but Metropolitan Mandic suspected that the goal of the people's leaders was not to reach an agreement but instead to bring down the government, and it was not clear, even to Metropolitian Letica himself, what Bishop Mandić meant by 'bringing down the government'. ${ }^{31}$ On May 1, 1901, Risto Damjanović told Jeftanović what Metropolitan

\section{Sarajevski list, br. 67, 7. jun 1901.}

Madžar 1982: 328-329.

Translation of Todor Pišteljić's letter to Gligorije Jeftanović on April 25, 1901:

'Our Metropolitan Letica told me that the day before our conversation he had received a letter from Metropolitan Mandić, who wrote that the people's leaders were not pleased with the Metropolitane's answer, and that you went via Vienna and Pest to see Emil Gavrila and that there you complied a new letter for the Metropolitanate, even though you had been advised to cease futher correspondence and written communication and to continue with verbal negotiations.

'His Eminence Metropolitan Letica tells me that upon your return from Vienna you invited your associates by telegram to a meeting and discussion in Sarajevo, and that on Thursday and Friday (as Mandić wrote to him) you held your own meetings at which you decided to enter into an alliance and treaty with the Turks and to go together with them to Vienna (but each side on its own behalf if it was more beneficial) and lodge a complaint either in league with the Turks or alone.

'His eminence Metropolitan Letica also tells me that our Metropolitan Mandić writes that you, our leaders, are not concerned with resolving our Church and school autonomy, but rather your intention is to bring down the government. My question to him was, which government? Letica answered that even he didn't understand where Mandić got that idea from, and that Mandić meant either bringing down the Bosnian government or forcing Austria Hungary out of Bosnia. I commented that, to me, this looked like a denunciation of our leader because bare hands cannot bring down or force out a very powerful state and government like Austria-Hungary. Mr. Letica answered that by saying that he himself did not know what Mandić wanted to say'. Historijski arhiv 
Mandić was doing in the Metropolitanate of Dabar-Bosnia, and that the metropolitan was working behind the backs of the leaders of the people's movement. He further wrote that those in Sarajevo had written to Vojislav Šola in Mostar asking if the Metropolitan of Herzegovina was doing the same, and that those in Sarajevo thought he (meaning Jeftanović) or Šola should be conducting the negotiations. ${ }^{32}$

Of particular interest are the letters Lazar Pupić sent regularly from Sarajevo to Jeftanović in Vienna from May 3/16 to 10/23, 1901 regarding the selection of a Serbian envoy from the Metropolitanate of Dabar-Bosnia who would be sent to Constantinople to speak with the Ecumenical Patriarch. In the first letter, Pupić confirmed the allegations made in a letter Todor Pišteljić had sent to Jeftanović about what Bishop Mandić was doing regarding the selection of a representative for the negotiations at the Ecumenical Patriarchate. In the same letter, he also expressed his doubts concerning what Metropolitan Mandić's intended to do if his candidate was not chosen. He claimed the metropolitan might sabotage the election in order to delay information about who would receive the trust of the communes, and such a delay would mean that the chosen delegate would not be able to leave soon enough to arrive in Constantinople at the appointed time. ${ }^{33}$ Upon receiving the

Sarajevo, Fond porodice Jeftanović, kutija br. 3, OJ-867 (HAS, FPJ).

32 Text of a letter Risto Damjanović sent to Gligorije Jeftanović on May 1, 1901:

'...I'm sending you copy of the notice Metropolitan Mandić sent last night to each commune in his diocese. Since this is a very important act - who the Srb. and chr. parishes put their trust in and what kind of person will be chosen to represent the Srb. Orthodox people of Bosnia through this replacement-we found it necessary to also send Laza to Mostar today and to inform Vojislav and to see if the Hercegovinian metropolitan sent this notice. Since time is short, Vojislav will contact you from Mostar by telegram. We here are of the opinion that Vojislav will contact the communes this evening by telegram and tell them to delay the meetings until you point out the candidate. We've heard that the metropolitan has privately recommended his own candidate, but we don't know who?

'Father Stjepo's opinion is that if you can't accept, then Vojislav should be presented as the candidate. I'm worried that the metropolitan will find something else to quibble about because the notice clearly states, 'from this diocese'. HAS, FPJ, kutija br. 3, OJ-878.

33 Translation of the first letter Lazar Pupić sent to Gligorije Jeftanović on May 3/16, 1901:

'...On Monday evening we found out privately that Metropolitan Mandić had sent out a notice to all municipalities in his diocese asking for each municipality to choose an envoy to send to Constantinople, so I asked the priest and Hadžić to consult with me. There wasn't much time, I wasn't able to send Vojislav a detailed telegram and a letter would arrive too late, so I asked the priest and Hadžić if one of them could go to Mostar, but one excused himself saying his wife was sick, and the other said he was about to travel, so they decided I would have to go, and so, fearing we wouldn't achieve our goal, I left day before yesterday on Monday for Mostar and then came back to Sarajevo yesterday. I met with Šola in Mostar, and we agreed to send you a telegram, and we received your answer yesterday at $9 \mathrm{am}$. Then we sent you a telegram saying that Vojislav couldn't be chosen because he's not in Mandić's diocese and you would need to choose someone else. I couldn't wait for your answer to our second telegram, and I left for Sarajevo, however last night I received a dispatch from you in which you said that you had informed Voja that Kosta would be nominated. Yesterday I received a telegram from Voja in which he said that you had nominated Kosta and that he had sent telegrams to all of the communes in the Diocese of Dabar-Bosnia. There is still the tricky question of if the metropolitan will have time to get in touch if Kosta is elected, and will I have time to inform Kosta, because by the $7^{\text {th }}$ of this month by the Julian calendar. it will be known that evening who received the most votes. Kosta needs to know this by the $7^{\text {th }}$ at the latest so he can leave on the 8 th and catch the Brodski train that same day so he can get to Constantinople by the $11^{\text {th }}$. I doubt we'll manage because the metropolitan will ask for a delay specifically so our candidate won't be able to leave in time. Just in case, I'll write to Kosta today and explain 
letter on May 3/16, that same day Jeftanović sent a letter to Pupić from Vienna, in which he told him that, in order to avoid the possibility of the election being sabatoged, the best candidate would be Kosta Kujundžić, but they should also be prepared to act if the metropolitan did indeed attempt sabotage. ${ }^{34}$

After receiving this letter, Pupić sent Jeftanović an answer on May 4/17, telling him that Metropolitan Mandić had sent a notice to eighty locations within his metropolitinate, including even small rural settlements, and that he had written to Vojislav Šola to go to Sarajevo immediately to protest to the metropolitan about this election, which he considered to be illegal. ${ }^{35}$ Pupić sent another letter on May 6/19, in which expressed doubt that the candidate to lead the Serbian movement, Kosta Kujundžić, would receive more than eighty votes, but that he (Jeftanović) would be told of the outcome when voting was completed ${ }^{36}$ The next day, he announced that Kujundžić had been elected and that he would leave the following day for Constantinople, and that he had requested 200 forints for the journey. ${ }^{37}$

In response to the allocation of 200 forints for the journey, Jeftanović answered Pupić on May 8/21, expressing his dismay at Kujundžić's request being granted, to which Pupić answered that he agreed, but that Šola had promised the loan would be repaid, and Kujundžić had already left for Constantinople. ${ }^{38}$ Kujundžić informed Jeftanović on May $12 / 25$ that he had arrived in Constantinople the previous day. ${ }^{39}$ It was at this point that a change came about concerning the head of the Ecumenical Patriarchate. Strong opposition in the Synod emerged against Patriarch Constantine V, and he was replaced by Joachim III.

Jeftanović wrote to Kujundžić on May 17/30 to tell him about his audience with the emperor. ${ }^{40}$ Kujundžić informed Jeftanović of the following in a May 19/June 1 letter, in which he also said he had met with the former patriarch.

'...The election of the patriarch will be held on Wednesday, they told me-and I will go to the election as a representative because there has been no protest against me..I visited with Patriarch Constantine on Sunday...he told me that he had written to the bishops about their proposal to the Patriarchate to draw up a draft constitution...that they should do it themselves, but in no other way than in agreement with the people-he even asked me if they had done this - I answered that they had-but without any agreement from the people...he mentioned that he could not believe they had done it that way - when the people should have participated in it... ${ }^{41}$

everything so he'll be prepared to leave on the 8th of this month by the Julian calendar and catch the train in Lašva so he can present himself in Constantinople on the $11^{\text {th }}$ of this month. When you receive this letter, immediately send Kosta a telegram telling him to be ready for Constantinople, and that if he receives a telegram from me on the $7^{\text {th }}$ of this month by the Julian calendar, then he should leave on the 8th to arrive in time for the election...It would really be shameful if no one you'd chosen went to Constantinople'. HAS, FPJ, kutija br. 3, OJ-880

34 HAS, FPJ, kutija br. 3, OJ-879.

35 HAS, FPJ, kutija br. 3, OJ-881.

HAS, FPJ, kutija br. 3, OJ-883.

HAS, FPJ, kutija br. 3, OJ-884.

HAS, FPJ, kutija br. 3, OJ-885; OJ-886.

HAS, FPJ, kutija br. 3, OJ-871.

HAS, FPJ, kutija br. 3, OJ-874.

HAS, FPJ, kutija br. 3, OJ-873. 
Kosta Kujundžić attended the ceremony at which Joachim III was named Patriarch, after which he was granted an audience with him as the respresentative of the Serbian people in Bosnia-Herzegovina. However, the new patriarch also held the same views as his predecessor and did not think that the Austro-Hungarian authorities interfering in the affairs of the Orthodox people's confessional schools in Bosnia-Herzegovina. ${ }^{42}$

At the end of October 1901, the metropolitans and the Provincial Government in Sarajevo sent their opinions regarding the third memorandum to the joint finance minister. As it had with the previous two memoranda, the Provincial Government also considered this one to be untrue and the work of 'Serbian demagogues', but the metropolitans, however, did not have unified position regarding it. In their response, the metropolitans claimed that foreign influence was the main instigator of the movement for autonomy, and believed that the episcopal authorities had divine right and could not be limited by any kind of human force ${ }^{43}$ The memorandum was then rejected.

Reviewing the newly developed situation, the leaders of the Serbian autonomy movement concluded that the emperor should be addressed again through a new memorandum asking him to force the government to finally resolve the Serbian issue. The emperor received the deputation on June 5, 1902, and they presented their fourth imperial memorandum, which emphasized in particular that, after they had presented the third memorandum, nothing had been done to resolve the issue of self-management despite promises made that it would be. ${ }^{44}$ The government rejected this memorandum. New steps by the leaders of the Serbian movement followed. In September 1902, ${ }^{45}$ the Serbian deputation, headed by Jeftanović, traveled to Constantinople to present the memorandum concerning the situation in Bosnia to the Patriarch, and to inform him that the Serbian people would not accept the imposition of a statute without the prior conset of their leaders. Unlike the previous attempts, this one bore fruit, especially since the Patriarch's secretary arrived in Sarajevo in May of the following year and had been tasked with speaking with the metropolitans. ${ }^{46}$

The Statute Regulating Church and School Autonomy was promulgated in 1905. When the statute was adopted by the Synod of the Ecumenical Patriarchate, the leaders of the autonomy movement came in for harsh criticism from young Serbian intellectuals in Bosnia-Herzegovina, who were dissatisfied with the outcome. ${ }^{47} 48$ The younger generation thought the struggle should continue by moving on to new social and purely political

\footnotetext{
Madžar 1982: 330.

Ibid: 328.

Madžar 1982: 347; Kruševac 1960: 305.

In August 1902, before arriving in Constantinople, the leaders of the movement wrote a memorandum concerning the Serbian people's position in Bosnia-Herzegovina, which was signed by Father Stevo Trifković, Father Mihailo Jovičić, Gligorije Jeftanović, and Vojislav Šola and was then officially presented in Belgrade so King Aleksandar Obrenović could bring it to Russia and present it to the Russian emperor. However, since King Aleksandar did not travel to Russia, the memorandum was then translated into Russian and given to the emperor by Stojan Novaković, the Russian ambassador. Kecmanović 1965: 396; Branković 2017v: 37.

46 Kruševac 1960: 305.

47 The differences in understanding between the older and younger generations of the Serbian elite was also attested to by the head of the Mostar commune, Baron Pinter. Mastilović 2011: 36; Milošević 2017: 75.

Branković 2018: 186; Masleša, 1956: 19; Mikić 1995: 301; Buha 2006: 54-55; Milošević 2017: 75.
} 
issues. ${ }^{49}$ They considered the acceptance of the statute to be a betrayal of Serbian national interests in Bosnia-Herzegovina. ${ }^{50}$ Unlike the younger intellectuals, Jeftanović and most of the autonomy movement's leaders thought the time had come to shift the struggle toward economic issues. ${ }^{51}$ Gligorije Jeftanović was fiercely attacked by the young intellectuals because he had campaigned so hard for the statute to be accepted and abided by. Petar Kočić harshly criticized the movement's leaders because they had sidestepped agrarian issues during the nine-year struggle, which he felt was an issue of upmost importance for the Serbian peasants. ${ }^{52}$ Vasilj Grđić was also critical of them. After the decree was accepted, he wrote, 'All I can say is that you have not heard the last word from the people, and the statute was not instated with their consent. This is why the statute was not accepted anywhere with great pleasure'. Criticism of Jeftanović from Banja Luka was especially harsh. ${ }^{53} \mathrm{He}$ was accused of betraying Serbian interests and tearing apart the Serbs and their struggle. ${ }^{54}$

All in all, it can be concluded that the Serbian autonomy movement emerged as a response to the Austo-Hungarian government's oppression of the Serbian population in Bosnia-Herzegovina - not so much because of economic issues, but because of the reprisals against the national name, language, and faith. The movement was entirely based on national and political issues, within which not much thought was given to socioeconomic circumstances, and which raised the leaders of the movement to new heights as champions of the preservation of Serbian national identity. However, toward the end of struggle and the adoption of the statute, and with the rise of university-educated Serbian intellectuals, the idea of expanding the struggle for autonomy to economic issues at the state level was strengthened, which put those of the older generation like Gligorije Jeftanovic in an awkward position. The younger intellectuals felt that Church and school autonomy did not completely fulfill the needs of the Serbian people, and that accepting the statute was akin to a betrayal of Serbian national interests. However, the older generation, the leaders of the struggle for autonomy, believed they had achieved the most that was possible during their nine-year struggle.

Translated by Elizabeth Salmore

\section{REFERENCES:}

Archival Sources:

HAS Historijski arhiv Sarajevo - Fond porodice Jeftanović

Newspapers:

Kobasica, S. 'Gligorije Jeftanović', Politika, 6.785, 16. mart 1927. (Serbian Cyrillic)

Sarajevski list, br. 67, 7. jun 1901. (Serbian Cyrillic)

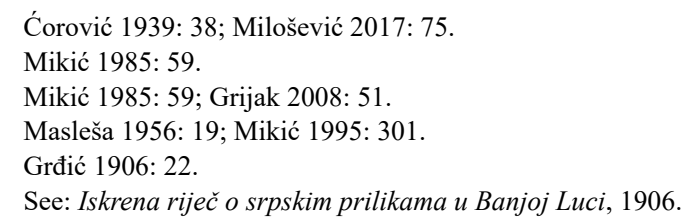


References:

Berić, D. Ustanak u Hercegovini 1852-1862, Beograd-Novi Sad: SANU, Udruženje Srba iz Hercegovine u Vojvodini, 1994. (Serbian Cyrillic)

Branković, B. M. 'Correspondence between Gligorije Jeftanović and The Great Administrative and Educational Council in 1919', Istraživanja - Journal of Historical Researches, 30, 2019, 187-196. . 'Da li se istorija borbe za autonomiju srpskog naroda u Bosni i Hercegovini ponavlja?', u: M. Kulić, M. Letić (ur.), Nauka i stvarnost, knj. 12, tom I, Zbornik radova, Pale: Univerzitet u Istočnom Sarajevu, Filozofski fakultet, 2018, 179-198. (Serbian Cyrillic)

. 'Od polubogova do nacionalnih izdajnika i optuženika za veleizdaju', u: Đ. Čekrlija (ur.), Ličnost i društvo III: Autoritarna ličnost i društvo, Zbornik radova, Banja Luka: Univerzitet u Banjoj Luci, Filozofski fakultet, Friedrich Ebert Stiftung BiH, 2017b: 27-34. (Serbian Cyrillic) . 'Spoljni uticaji na kontakte predstavnika srpskog i muslimanskog pokreta za vjerskoprosvjetnu samoupravu', u: B. M. Branković, B. Milošević (ur.), Stotinu dvadeset godina od početka borbe srpskog naroda u Bosni i Hercegovini za crkveno-školsku samoupravu (18962016), Zbornik radova, Banja Luka: Univerzitet u Banjoj Luci, Filozofski fakultet, 2017a: 89103. (Serbian Cyrillic)

. 'Spoljnopolitičko pitanje borbe srpskog naroda u Bosni i Hercegovini za autonomiju od 1850 do 1878. godine', Glasnik Udruženja arhivskih radnika Republike Srpske, 7, 2015, 37-47. (Serbian Cyrillic)

. 'Značenie pis'ma serbskih predvoditeleî o cerkovnô̂ avtonomii Bosnii i Gercegoviny napravlennoe russkomu carju v 1902. g', Monah Veniamin (A.V. Semenov) (ur.), Vmeste skvoz ' veka. $K$ istorii russko-serbskih kul'turnyh, duhovnyh $i$ političeskih svjazê, Materialy meždunarodnoî naučno-praktičeskoî konferencii, Sankt Peterburg: Komitet po mestnomu samoupravleniju, mežnacional'nym i mežkonfessional'nym otnošenijam Leningradskoî oblasti, Gatčinskaja Eparhija Russkoî Pravoslavnoî Cerkvi, 2017v, 36-42. (Russian Cyrillic)

Branković, B. M. Milošević, B. 'Povodom 120 godina od početka borbe Srba za crkveno-školsku samoupravu u Bosni i Hercegovini', Radovi, 24, 2016, 13-25. (Serbian Cyrillic)

Buha, M. M. 'Mlada Bosna'- sarajevski atentat. Austrougarska vladavina Bosnom i Hercegovinom 1878-1918, Istočno Sarajevo: Zavod za udžbenike i nastavna sredstva, 2006. (Serbian Cyrillic)

Ćorović, V. Političke prilike u Bosni i Hercegovini, Beograd: Politika, 1939. (Serbian Cyrillic)

Giljferding, A. Putovanje po Hercegovini, Bosni i Staroj Srbiji, Sarajevo: Veselin Masleša, 1972. (Serbian Cyrillic)

Grđić, V, Riječ dvije o našem sporu, Novi Sad: izdanje piščevo, 1906. (Serbian Cyrillic)

Grijak, Z. 'Srpska pravoslavna crkva u Bosni i Hercegovini tijekom austrougarske vladavine u novijoj domaćoj i inozemnoj historiografiji', Croatica Christiana periodica, 61, 2008, 29-62.

Hadžijahić, M. 'Formiranje nacionalnih ideologija u Bosni i Hercegovini u XIX vijeku', Jugoslovenski istorijski časopis, 1-2, 1970, 55-70.

Iskrena riječ o srpskim prilikama u Banjoj Luci, Sarajevo: Prva srpska štamparija Riste J. Savića, 1906. (Serbian Cyrillic)

Juzbašić, Dž. 'Pokušaji stvaranja političkog saveza između vođstva srpskog i muslimanskog autonomnog pokreta u Bosni i Hercegovini', Prilozi, 14-15, 1978, 145-146.

Kecmanović, I. 'Jedna epizoda iz borbe Bosne i Hercegovine za crkveno-školsku autonomiju', Glasnik Arhiva i Društva arhivskih radnika Bosne i Hercegovine, 4-5, 1965, 369-396.

Ković, M. Dizraeli i Istočno pitanje, Beograd: CLIO, 2007. (Serbian Cyrillic)

Kraljačić, T. Kalajev režim u Bosni i Hercegovini 1882-1903, Sarajevo: Veselin Masleša, 1987.

Kruševac, T. Sarajevo pod austro-ugarskom upravom 1878-1918, Sarajevo: Muzej grada Sarajeva, 1960. (Serbian Cyrillic)

Lotoc'kiî, O. Avtokefalija, tom II, Varšava: Pracì Ukraìns'koğo Naukovoğo İnstitutu, 1938. (Ukrainian 
Cyrillic)

Madžar, B. Pokret Srba Bosne i Hercegovine za vjersko-prosvjetnu samoupravu, Sarajevo: Veselin Masleša, 1982. (Serbian Cyrillic)

Madžar, B. Papić, M. Politika i Srpska pravoslavna crkva u Bosni i Hercegovini 1878-1945, Banja Luka: SPKD Prosvjeta GO Banja Luka, 2005. (Serbian Cyrillic)

Marković, S. 'Prožimanja stavova o nacionalnoj ideji Srba iz Bosne i Hercegovine i Srba južne Ugarske (Vojvodine) početkom 20. veka', u: D. Mikavica (ur.), Srbi na prostoru Bosne $i$ Hercegovine od XV do XX veka, Zbornik radova, Novi Sad: Filozofski fakultet, 2020, 411-432. (Serbian Cyrillic)

Masleša, V. 'Grupa Otadžbina', Korijen, 8-9, 1956, 19-22.

Mastilović, D. 'Geneza nastanka novovjekovne srpske elite u Bosni i Hercegovini', u: M. Kovačević, M. Pikula (ur.), Nauka i politika, knj. 5, tom II, Zbornik radova, Pale: Univerzitet u Istočnom Sarajevu, Filozofski fakultet, 2011, 27-44. (Serbian Cyrillic)

Mikić, Đ. 'Autonomija kao kategorički imperativ srpske samoodbrane', u: R. Kuzmanović, D. Mirjanić (ur.), Republika Srpska - dvadeset godina razvoja - dostignuća, izazovi i perspektive, Zbornik radova, Banja Luka: ANURS, 2012, 521-539. (Serbian Cyrillic)

. 'Pregled društveno-ekonomskog i političkog života u Bosanskoj krajini u razdoblju austrougarske uprave (1878-1914)', Istorijski zbornik, 6, 1985, 41-67.

. Banja Luka na Krajini hvala, Banja Luka: Institut za istoriju, 1995. (Serbian Cyrillic)

Milošević B. Lukić, S. 'The Serbian Orthodox Church and Serbian education in Bosnia-Herzegovina in the last century of Ottoman rule', Istraživanja - Journal of HISTORICAL Researches, 31, 2020, 131-149.

Milošević, B. 'Uredba crkveno-prosvjetne uprave srpskih pravoslavnih eparhija (mitropolija) u Bosni i Hercegovini', u: B. M. Branković, B. Milošević (ur.), Stotinu dvadeset godina od početka borbe srpskog naroda u Bosni i Hercegovini za crkveno-školsku samoupravu (1896-2016), Zbornik radova, Banja Luka: Univerzitet u Banjoj Luci, Filozofski fakultet, 2017: 71-88. (Serbian Cyrillic)

Papić, M. Hrvatsko školstvo u Bosni i Hercegovini do 1918. godine, Sarajevo: Veselin Masleša, 1982.

Radojčić, S. J. Srbi zapadno od Dunava i Drine, knj. II, Novi Sad: IK Prometej, 2009. (Serbian Cyrillic)

Ruvarac, D. Ustav crkvene i školske samouprave srpsko-pravoslavnog naroda u Bosni i Hercegovini sastavljen Dr. Emilom Gavrilom, Zemun: Štamparija Jovana Pulja, 1899. (Serbian Cyrillic)

Slijepčević, Đ. Pitanje Bosne i Hercegovine u XIX veku, Keln: autorsko izdanje, 1981.

Šneler, H. Državno-pravni položaj Bosne i Hercegovine, Beograd: Izdanje Književnog fonda Ilije M. Kolarca, 1893. (Serbian Cyrillic)

Tomić, M. 'Crkvenopravna pitanja Srpske pravoslavne crkve u Bosni i Hercegovini za vreme austrougarske uprave', Zbornik radova Pravnog fakulteta u Nišu, 84, 2019, 331-347.

Urić, N. 'Jeftanović, Gligorije M.', u: Srpski biografski rečnik, tom 4, Novi Sad: Matica srpska, 2009, 399-401. (Serbian Cyrillic)

Vasin, G. 'Srpski crkveno-narodni sabori i pitanje crkveno-školske autonomije u Habzburškoj monarhiji 1867-1918', u: B. M. Branković, B. Milošević (ur.), Stotinu dvadeset godina od početka borbe srpskog naroda u Bosni i Hercegovini za crkveno-školsku samoupravu (18962016), Zbornik radova, Banja Luka: Univerzitet u Banjoj Luci, Filozofski fakultet, 2017: 5170. (Serbian Cyrillic)

Vlatković, D. 'Jazavac pred sudom kao povod i podsticaj za političko raslojavanje i grupisanje bosanskohercegovačke omladine' u: D. Đuričković (ur.), Petar Kočić, Zbornik radova, Sarajevo: Institut za jezik i književnost, 1979, 331-343. (Serbian Cyrillic) 


\author{
БОШКО М. БРАНКОВИЋ \\ Универзитет у Бањој Луци \\ Филозофски факултет
}

\title{
ГЛИГОРИЈЕ ЈЕФТАНОВИТ И БОРБА СРБА ЗА ЦРКВЕНО-ШКОЛСКУ АУТОНОМИЈУ
}

\begin{abstract}
Резиме
Борба српског народа за веће слободе и права у Херцеговини и Босни добила је замах почетком 19. вијека. Од тада, Срби су непрестано постављали питање аутономије или потпуног ослобођења испод османске власти. Питање права Срба у покрајинама Босни и Херцеговини постаје нарочито актуелно половином 19. вијека, када Срби почињу да теже ослобођењу и уједињењу са Србијом и Црном Гором. Српски устанак 1875. године у Херцеговини и Босни против османске државе по први пут је дао за право Србима у овим покрајинама, да од Великих европских сила траже могућност да се припоје Србији и Црној Гори. Међутим, нису све европске државе благонаклоно гледале на могућност да ове покрајине добију аутономију или да се припоје Србији и Црној Гори. Аустроугарска монархија извршила је окупацију покрајина на основу одлука Берлинског уговора из 1878. године. Једно од најважнијих питања за аустроугарске власти било је регулисање положаја српске православне цркве и српских конфесионалних школа. Због одузимања права у области вјерског и школског живота Срба, српски народ се одлучио на отпор аустроугарским властима. Српски покрета за црквеношколску самоуправу, који је званично покренут 1896. године, избацио је у јавност народно незадовољство према репресијама које су спровођене над становништвом од стране аустроугарске власти. Покрет је на историјску сцену гурнуо српску градску елиту. Заједничко иступање више српских црквено-школских општина 1896. године значило је стварања организованог покрета на чијем челу су се, између осталих, посебно истакли Глигорије Јефтановић из Сарајева и Војислав Шола из Мостара. Јефтановић је у деветогодишњој борби за црквено-школску аутономију достојно представљао српски народ. Заједно са својим сарадницима успио је 1905. године издејствовати усвајање Уредбе о уређењу самоуправних црквено-просвјетних прилика. Међутим, по усвајању Уредбе, али и коју годину раније, јављају се противници у виду млађе, факултетски образоване српске интелигенције из Босне и Херцеговине, који су сматрали да се може и треба више тражити од добијеног и да борбу треба наставити. Јефтановић је означен као издајник српских националних интереса.
\end{abstract}

Кључне речи: Глигорије Јефтановић, црквено-школска аутономија, борба, Аустроугарска монархија, Васељенска патријаршија, Срби, Босна и Херцеговина. 